\title{
CONSIDERATIONS REGARDING THE EVOLUTION OF THE STEEL THERMAL STATE IN THE CONTINUOUS CASTING PLANT
}

\author{
Marian BORDEI \\ "Dunarea de Jos" University of Galati Romania \\ e-mail: mbordei@ugal.ro
}

\begin{abstract}
In continuous casting it is very important that the cooling system is correctly dimensioned. Improper cooling conditions can reduce the quality of the finished product and cause perforations of the solidified crust. In order to be able to minimize the occurrence of defects, it is preferable that, under the conditions of a given cooling system, the temperature distribution in the steel wire be known. It is also necessary to know the thickness of the solidified crust, especially immediately below the crystallizer, because a thin crust at this level can be perforated due to the ferrostatic pressure of the steel. The knowledge of the thermal state of the steel in the continuous casting installation is necessary for the transposition on mathematical bases of the technological process and the elaboration of some models of simulation of the solidification, which would allow to optimize the operation of the afferent installations.

By considering the convection motion can be explained the influence of electromagnetic agitation and deformation of the steel wire on the incompletely solidified area on the quality and structure of cast steels; convective currents reduce overheating, which leads to a decrease in columnar crystallization in favour of axial crystallization. By running the simulation program were determined the variation of the thermal flux at different levels in the tundish, as well as the evolution of the temperature at the surface of the continuously cast steel thread.
\end{abstract}

KEYWORDS: continuous casting, solidification process, mathematical model

\section{Theoretical considerations}

Mathematical simulation models render the thermal field of the continuously cast steel thread as a function of some process parameters: casting speed, steel overheating, thermophysical properties of the tundish material, steel quality, tundish geometry, etc.

Some important operational variables such as: tundish length, cooling system, metallurgical length and casting speed - are conditioned by the heat transfer during the process. The quality of the semifinished product is significantly influenced by the speed of heat extraction, excessive cooling leading to cracks, swelling of the thread, large columnar areas, etc.

Because thermal conductivity has a major role in the process of continuous casting, on its base, several mathematical models have been developed, and they were used to analyse the stresses that are formed when the crust solidifies; they contribute to the understanding of the causes of surface defects and internal cracks. They are used to improve cooling systems, casting technologies and process control.

Hills and Mizikar are among the first authors who wrote about the modeling of the heat flow in the continuous casting system. Hills [1] used a thermal balance method to solve the problem of thermal conductivity and solidification in a complex system, such as continuous casting; he neglected the conductivity of the steel in the direction of the thread flow and considered the overheating in the liquid area to be zero.

Mizikar [2] applied the finite element method to develop the two-dimensional heat conduction equation for continuously cast slabs. He also developed the one-dimensional conductivity transfer equation, Fourier type, for a moving element - from the meniscus to the exit of the machine - predicting the temperature distribution along the length of the continuous cast thread. He integrated the convective aspect of heat transfer from the liquid into a model based on the conductivity of steel by increasing the conductivity coefficient. 
Many of the continuous casting machines are designed based on experience, on models established through simulations and tests, and on empirical relationships. The management of the continuous casting process is, in many cases, based on models with low applicability.

The alloy used for the research is a generalpurpose carbon steel for construction S235J2G4, according to EURONORM 10025 (OL 37-4k, according to STAS 500). The thermophysical parameters of steel solidification were calculated according to studies and research in the literature [3].

\section{Results obtained}

The temperature field in the continuous cast thread can be represented by the fundamental equation of thermal conductivity (Fourier equation). Based on the data from the program, the relations used for the calculation of the main parameters that give the thermal state of the continuously cast steel thread were determined.

Running the program, it was determined: the variation of solidified crust thickness as a function of time, the overheating in the tundish and the convection coefficient (Figures 1,2), the variation of the thermal flux at different levels in the tundish (Figure 3), as well as the surface temperature evolution. of continuously cast steel thread (Figure 4) [4].

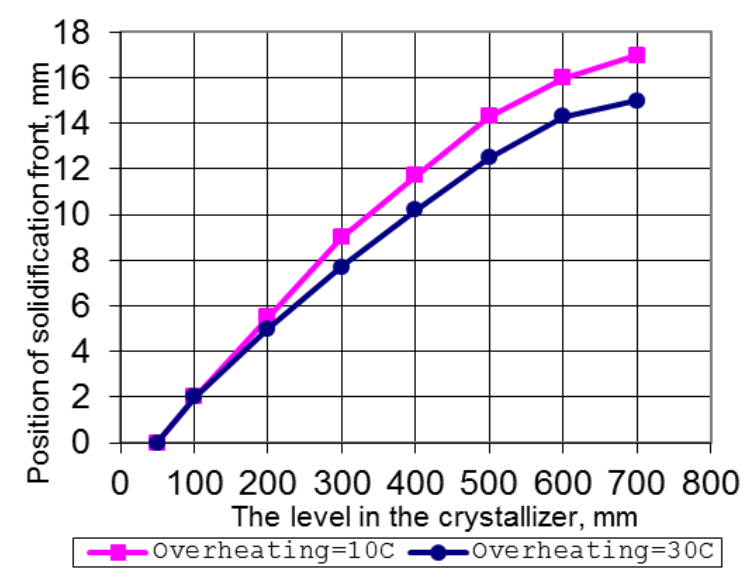

Fig. 1. The thickness of the crust solidified at different levels in the tundish for two values of steel overheating

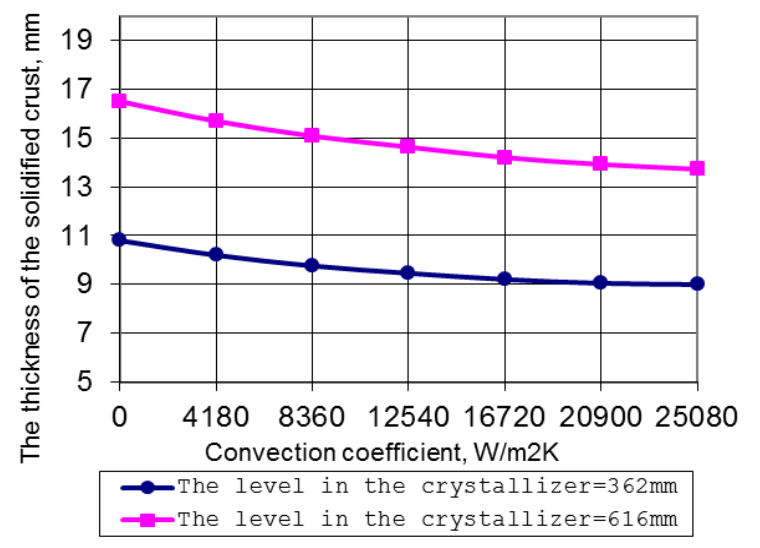

Fig. 2. The variation of the solidified crust thickness depending on the convection coefficient at different levels in the tundish

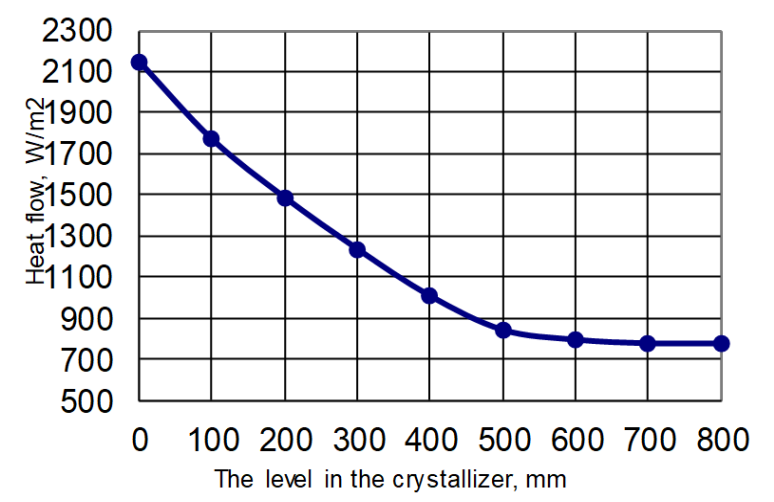

Fig. 3. Variation of heat flux at different levels in the tundish $(v=1 \mathrm{~m} / \mathrm{min})$

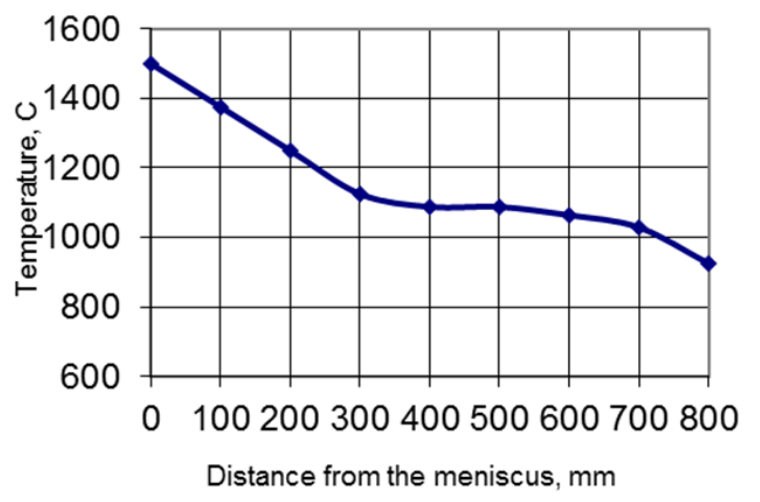

Fig. 4. Temperature distribution at the surface of the steel thread, in the middle of the face $(v=$ $1 \mathrm{~m} / \mathrm{min}$ )

\section{Interpretation of results}

The highest heat flux density occurs in the meniscus (Figure 3), the fall that follows is explained by the following mechanism: 


\section{THE ANNALS OF “DUNAREA DE JOS” UNIVERSITY OF GALATI \\ FASCICLE IX. METALLURGY AND MATERIALS SCIENCE \\ $N^{\circ} .4$ - 2020, ISSN 2668-4748; e-ISSN 2668-4756 \\ Article DOI: https://doi.org/10.35219/mms.2020.4.05}

- by increasing the crust of the steel thread, the ferrostatic pressure exerted on the wall of the tundish decreases, the heat transfer worsens;

- by decreasing the temperature of the thread surface, the contraction is increased (shrinkage of the thread crust), fact that contributes to the amplification of the mentioned effect;

- the growing crust of the thread worsens the heat flux discharged from the tundish due to low temperature gradients and increasing thermal resistivity.

The cooling curve in Figure 4, calculated at an extraction speed of $1 \mathrm{~m} / \mathrm{min}$, shows the temperature drop from the beginning of the casting process (solidification), in this phase there is still a good heat transfer between the thread surface and the tundish. As the casting process continues, the heat transfer worsens, the cause being mainly the increase of the gap between the tundish and the solidified crust, as well as the modification of the thermal conductivity properties of the slag film. Given that the heat flux from the surface of the thread to the tundish is now lower than that coming from inside the thread, a slight increase in temperature is reached at the surface of the thread.

\section{References}

[1]. Bamberger M., Mathematical model for the solidification of high-carbon steel in continuous casting, Iron and Sleel International, 2/1977.
[2]. Braun H., Computersimulation thermischer und mecanischer Vorgänge beim Brammenstranggieben von Stahl, Stahl und Eisen, p. $79-85,9 / 1996$.

[3]. Oprea S., Corelaţia dintre proprietăţile termofizice şi mecanice ale materialelor metalice cu procesul de încălzire, Metalurgia, p. 435-445, 7/1973.

[4]. Bordei M., Considerente privind deformarea plastica a semifabricatelor turnate continuи in scopul optimizarii unor parametri ai proceselor de turnare continua-laminare, Teză de doctorat, Galati, 1999.

[5]. ***, Continuous Casting, vol. 1-9, Iron and Steel Society, 186 Thorn Hill Road, Warrendale, PA 15086-7512, 1979-1997.

[6]. ***, Modeling of Casting and Welding Processes, Conference Series, vols. 1-10, TMS, Warrendale, PA.

[7]. ***, Continuous Casting, in The Making, Shaping, and Treating of Steel, vol. 2, A. Cramb, ed. Pittsburgh, PA: Assoc. of Iron \& Steel Engineers, 2003.

[8]. Bratu V., Mortici C., Oros C., Ghiban N., Mathematical model of solidification process in steel continuous casting taking into account the convective heat transfer at liquid-solid interface, Computational Materials Science, vol. 94, November 2014.

[9]. Oprea S., Corelaţia dintre proprietăţile termofizice şi mecanice ale materialelor metalice cu procesul de încălzire, Metalurgia, p. 435-445, 7/1973.

[10]. Rogberg B., Testing and Application of a Computer Program for Simulating the Solidification Process of a Continuous Cast Strand, Teză de doctorat, Stockolm, 1990.

[11]. Bamberger M., Mathematical model for the solidification of high-carbon steel in continuos casting, Iron and Sleel International, 2/1977.

[11]. Barber B., Détermination de la température de surface sur ligne de coulée continue et du transfert thermique lors de la coulée continue, La Revue de Métallurgie-CIT, 11/1996.

[12]. Bordei M., Cercetări privind îmbunătăţirea randamentului de metal prin creşterea calităţii tablelor şi benzilor obţinute prin laminarea bramelor turnate continuu, Contract nr. 67/1996, beneficiar: SIDEX S.A Galaţi. 